\title{
The Arkansas RIver Valley: A New Paradigm, Revisionist Perspectives and the Archaeological Record
}

Robert L. Brooks

Oklahoma Archeological Survey

Follow this and additional works at: https://scholarworks.sfasu.edu/ita

Part of the American Material Culture Commons, Archaeological Anthropology Commons, Environmental Studies Commons, Other American Studies Commons, Other Arts and Humanities Commons, Other History of Art, Architecture, and Archaeology Commons, and the United States History Commons

Tell us how this article helped you.

This Article is brought to you for free and open access by the Center for Regional Heritage Research at SFA ScholarWorks. It has been accepted for inclusion in Index of Texas Archaeology: Open Access Gray Literature from the Lone Star State by an authorized editor of SFA ScholarWorks. For more information, please contact cdsscholarworks@sfasu.edu. 
The Arkansas RIver Valley: A New Paradigm, Revisionist Perspectives and the Archaeological Record

\section{Creative Commons License}

\section{(c) (1) \&}

This work is licensed under a Creative Commons Attribution-NonCommercial 4.0 International License 


\title{
THE ARKANSAS RIVER VALLEY: A NEW PARADIGM, REVISIONIST PERSPECTIVES AND THE ARCHAEOLOGICAL RECORD
}

\author{
Robert L. Brooks \\ Oklahoma Archeological Survey
}

\section{INTRODUCTION}

Recent articles by Schambach (1990a, 1990b, 1992, 1993a, and 1993b) have proposed a new paradigm for the late prehistoric period in the Arkansas River Valley. These arguments challenge traditional and long held views on the subsistence economy, architecture, material culture, biological character, and trade relationships of the prehistoric populations of the Arkansas River Valley, and the middle portion of the Red River (the Sanders phase area). My intention in this paper is to examine Schambach's arguments based on a comprehensive review of the archaeological record and by also drawing upon explanatory models of cultural and economic behavior. For the most part, my comments pertain to the Arkansas River Valley situation;
Bruseth, Wilson, and Perttula (1995) have responded to many of Schambach's challenges concerning the Sanders phase in the Red River Valley. Points here are not intended to defend the traditional perspectives as the gospel for the Arkansas River Caddoan tradition. Without doubt, a reexamination of the Arkansas River Caddoan is long overdue. Much of the subsistence data, bioarchaeology, and non-ceremonial aspects of the material culture were derived from analysis completed some 30 years ago, analysis conducted without the benefit of recent theoretical and methodological advances. However, we must reexamine the arguments and the data in an objective, informed fashion. Only from such an approach can we generate a new paradigm worthy of acceptance.

\section{REVISIONIST PERSPECTIVES}

\section{Subsistence}

In two recent articles Schambach $(1990,1993 a)$ has maintained that subsistence patterns in the Arkansas River valley during the late prehistoric period were substantially different from the economic mix of farming supplemented by hunting and gathering previously identified (Wyckoff 1980; Galm 1981). In brief, he proposes that people of the Northern Caddoan area were minor horticulturists with the major focus being on starchy seeds (e.g., chenopods, ama- ranth, and cucurbits) and on the use of bison as a meat source. He further argues that this system emphasizes hoe horticulture and grain processing with stone manos, grinding basins, etc., fostering extensive dental attrition. These claims merit further examination of the archaeological record. A casual review of the archaeological record does indeed suggest such a pattern. There are bison in the faunal assemblages from a number of sites in the Arkansas River Valley and 
there are certainly a number of questions concerning the horticultural practices of these Caddoan people. But, does this evidence bear up to closer scrutiny? Let us examine the data concerning these issues in greater detail.

Much of the emphasis on bison in the diet stems from the presence of bison bone in the faunal assemblages as well as the occurrence of bison bone tools at a number of Caddoan sites in the Arkansas River Valley. Here, Schambach (1990a) cites School Land I and II, Norman, Wybark, Sheffield, Tyler-Rose, Cookson, and Moore. I might add that there is also bison bone from the Craig and Copple mounds at Spiro. Most of the sites in question represent multiple occupations. Radiocarbon dates (uncorrected) from Sheffield (A.D. 1450, 1510), Tyler-Rose (A.D. 1500, 1530), and Moore (A.D. 1465, 1515) demonstrate the presence of later (post A.D. 1450) Fort Coffee phase occupations at these villages (Rhorbaugh 1984), occupations where bison procurement is recognized as a much more important part of the subsistence regime. The Cookson site, although not dated, also has a Fort Coffee (or Turkey Bluff) component that should date comparably to the Fort Coffee components found at the other sites referenced above (Israel 1969). The School Land I and II sites date to the Spiro phase and do contain bison. However, the MNI for bison at School Land I is 3 and only one individual is identified at School Land II. They are outnumbered by deer in the faunal assemblage at School Land I by 12 to 1 (Duffield 1969). In addition, the School Land sites are on the extreme northern periphery of the Caddoan area, situated on the Grand River in Delaware County adjacent to the tall grass prairie, and probably do not truly represent a setting comparable to other Arkansas River Valley sites. Where the subsistence data for Norman is derived from is uncertain as this site has not been analyzed. The presence of bison at Spiro (Copple and Craig mounds) is slight and does not appear to relate to use of bison as a food source. As Jim Brown (1984) discusses in his study of Spiro, evidence on engraved shell at the site clearly attest to the use of bison. How- ever, it is doubtful that this use extended beyond their selection for "wool" found in textiles. Certainly, no bison bone ornaments or tools appear in the Spiro mortuary assemblages. In retrospect, there is no supportive evidence for bison as a food staple during Harlan and/or Spiro phase times.

The presence of the starchy seeds complex at Spiro comes as no surprise. At Cahokia, consumption of large quantities of Chenopodium have been projected based on botanical samples (Lopinot 1991). The same situation has been found at a number of other southeastern Middle Mississippian ceremonial centers and settlements. Thus, the challenge here is to understand not the presence of these plants, but the apparent absence or limited use of tropical domesticates. Corn has been found at a number of Spiro phase sites including Norman, Bowman, Horton, and Jones. Of these, Horton, Bowman, and Jones contain multiple components and corn could come from later Fort Coffee phase occupations. Interestingly, there is corn pollen at Spiro and both kernels or cupules in limited numbers were identified in Fritz's (1989:73-75) analysis of botanical remains from Copple Mound. Fritz also found evidence for many seedy plants in the samples from Copple. These include Chenopodium and amaranth, maygrass, little barley, and knotweed, as well as an abundance of nutshell from acom, hickory, and pecan. This, coupled with Burnett's bioarchaeological evidence indicating little maize dependence at Spiro, is a fairly compelling argument for a subsistence economy tethered around a Woodland base of hunting, gathering, and limited gardening of the starchy seed complex. This still does not, however, explain why corn is present at Spiro in moderate quantities but never forms a substantive contribution to the diet.

There are some additional considerations as well. As recognized by Burnett (1989), their analysis of Arkansas River Caddoan populations was secondarily derived from prior work and was limited principally to ceremonial centers. For example, corn was recovered from 34SQ269 
in the Lee Creek valley with an uncorrected radiocarbon date of A.D. 1140 (Albert 1989). It is recognized that elites in stratified societies sometimes receive preferential diets (c.f., Pauketat 1994; Tainter 1980). Thus, the true order of magnitude of maize dependence (or lack thereof) can only be quantified through more systematic and representative study of Spiro phase populations. The other bioarchaeological question to be raised concerns the agricultural potential of Spiro phase people. The low level of maize dependency is based on cary rates found at Spiro and a few other studied centers. There should be some examination of what could be potentially masking cary rates. I would cite as an example the highly maize dependent Antelope Creek phase in the Texas and Oklahoma panhandles. There, cary rates are quite low due to the presence of fluoride in the water. We might also wonder whether starchy seeds might not also be an agent of tooth decay and why this evidence is lacking. Perhaps the high level of dental attrition from grit in the diet is obscuring some of the evidence. Such a situation has been found for agave consumption in Archaic hunter/gatherers of central Texas (Bement 1994).

Most of the village sites bearing on these subsistence questions were excavated before ethnobotanical sampling methodologies were widely practiced. The only two sites which have received detailed ethnobotanical analysis in southeastern Oklahoma are Spiro (Fritz 1989) and Bug Hill (Altchuel 1983). Thus, what is needed is substantive examination of flotation samples from Spiro phase villages. There is also a need to examine the issue of hoes found at Spiro phase villages. These are not the bison scapula, innominate, and hom core hoes found in Fort Coffee phase occupations (Rhorbaugh 1984), but chipped stone hoes of chert, argillite, and siltstone, as well as ones of shell. With only a minor emphasis on agriculture, why were hoes necessary at all? An examination of Boserup's (1964) model of agricultural growth attest to hoes being favored with greater agricultural intensity such as that found in a bush-fallow system, the next stage up in intensity from slash and burn. Another fundamental question concerns the issue of agriculture and domestication. Based on an overview by Fedick (1995:258261), you can have groups operating an agricultural system with non-domesticates and groups raising domesticates in a non-agricultural context. Obviously, multiple questions can be raised about the complex issue of maize dependency versus the eastern U.S. domesticates (Smith 1989), and a great deal more data and theoretical examination of the Arkansas River Valley subsistence base is needed before answers are readily available.

The last issue addressed in this area is the question of plant processing tools. Schambach (1993a) has emphasized that Arkansas River valley people made extensive use of stone manos and grinding basins with this being reflected by extensive tooth wear. Caddoan populations in southwestern Arkansas are apparently using nonabrasive agents to process their seed crops or are eating them green. However, the use of a ground stone technology to process seeds is by no means unique to the Arkansas River Valley. All of our Plains Village traditions extending across Oklahoma and Texas made extensive use of stone manos and metates. I include here virtually all of the cultural complexes of analogous times found along the Arkansas, Washita, Canadian, and upper Red rivers. Additionally, southwestern Pueblos were masters at ground stone processing of corn and other seeds. It is clear that the Caddo of the Lower Red River drainage probably had more in common with southeastern natives than their Arkansas River Valley counterparts in their plant processing techniques.

However, there are also exceptions to this which do nothing to resolve the basic issues here. At the Nelson site (34CH8), there are three burials recovered by the WPA from a nonmound context. The crania for these burials exhibit classic Sanders phase cranial (occipital) deformation. The teeth are in wonderful condition with no evidence of attrition from use of abrasives in the diet. These individuals also have classic Sanders phase ceramics as funerary 
objects. Thus, we have an anomaly. Does this represent a distinction in practices of Sanders phase populations or is it a matter of the remains and sites we have examined? While this question has a bearing on plant processing and technological adaptation, I fail to see the uniqueness of, and consequently the argument for, distinguishing Arkansas River Caddoans from other Caddoan groups on an issue that relates to how people process their seed crops and their ethnic origin.

\section{Adaptive Efficiency}

The concept of adaptive efficiency has played a major role in examining the physical well being of village farming populations (Burnett 1989). Because of their highly sedentary way-of-life and reliance on an agricultural base, the success of these populations' adaptation to their surroundings has been conducive to bioarchaeological analysis. Such analysis in the Arkansas River Valley has revealed high occurrences of periostitis, osteomyelitis, and osteoporosis in Spiro phase populations (Brues n.d.). Even with remote groups thought to be associated with Spiro, such as those whose remains were found at the Nagle site in Oklahoma County (Brues 1957), there is clear evidence of systemic infection. Schambach, following Brown's earlier lead, argues that this represents a sexually transmitted disease (in this instance syphilis). There is also a proposal that this condition extended to the Sanders site population.

A number of issues surround these paleopathologies. First, there exists considerable debate over the response of bone to infectious disease (Ortner 1991; Ortner and Putshar 1985). In addition, there has been substantial discussion of the definition and diagnosis of the various bone pathologies. Suffice it to say that currently there is not a consensus as to the causal agents involved with these conditions, certainly no wide acceptance of syphilis as the primary contributor. Most paleopathologists cautiously acknowledge that conditions such as osteomyelitis are physical expressions of the bone's response to long term, systemic, and chronic conditions, most likely bacteriological in nature. The impression that this is a condition that is expressed principally in the Spiro populations should also be approached with caution. There is evidence for these same pathologies in Wister and Fourche Maline phase populations in the Wister Valley. In fact, the Sam site contains one burial with evidence of osteomyelitis and a radiocarbon date of 300 B.C. occurring immediately above the burial feature (Galm and Flynn 1978). Thus, it is a long term condition within the region. I also suspect that it is highly associated with the "Black Midden Mound" settlement system. Kent (1989) has argued that these types of pathologies are an effect of highly sedentary lifestyles more than any other agent. Thus, the settlement serves as the vector for the diseases. This can be corroborated, to some extent, by the evidence of osteoporosis, periostitis, and osteomyelitis in Washita River and Antelope Creek phase populations -highly sedentary Plains Village groups. In fact, the ratio of individuals with this type of periosteal bone response may be no higher in the Arkansas River Valley than in Plains Village populations. Another issue addressed by Bumett and not discussed in the restudy of the Arkansas River valley is that burial samples expressing these conditions may be biased to infected individuals being interred in designated areas (e.g., midden mounds) rather than with those individuals who passed away from more traditional causes. In sum, these infectious diseases may potentially reflect a variety of bacteriological agents, a number of contributing vectors, and cultural and natural environmental factors.

From an alternative viewpoint, Owsley and his colleagues have recently demonstrated that syphilis was widespread among Northern Plains populations in late prehistoric and protohistoric times (Owsley, personal communication). The conditions which they use to document this social disease are the same osteomyelitis and periostitis found in the Southern Plains and the Arkansas River Valley. Based on chemical tests there appears to be little doubt that syphilis is almost epidemic in some groups in the Northern 
Plains.If the presence of conditions such as osteomyelitis and periostitis do indeed mark the presence of syphilis, then it is extremely common among both Plains Villagers and people of the Arkansas River Valley as rates of occurrence for these bone pathologies are almost identical. In fact, it is surprising that these conditions are not observed among the populations of southwestern Arkansas. Typically, social diseases are not especially discerning of political or social boundaries and we should be highly skeptical of the absence of syphilis-like attributes among Caddo populations in Arkansas and Louisiana. What this means is that the uniqueness of the Spiro people's condition is a false image. Most, if not all, late prehistoric groups across Oklahoma, portions of Texas, and yes, even portions of Arkansas probably had this condition as well. With these considerations in mind, it is not a useful vehicle for distinguishing the Arkansas River Valley people from their southern counterparts.

\section{Architecture and Material Culture}

A variety of issues pertaining to the material culture and architecture of the Arkansas River Valley's Spiro phase have been raised by Schambach (1992a). These include the presence of red slipped pottery, ceramics with fabric impressed bases, and house and mound architecture. The issues of a ground stone technology used in seed processing and the use of hoes in agriculture have been dealt with in a previous section.

The question of red-slipped pottery and its relation to the Spiro phase has existed for some time. In his work at Harlan, Bell (1972) noted that the site contained few of the red slipped wares that characterize the ceramic assemblage found at Spiro and other Spiro phase settlements. Does the appearance of these wares in the Spiro phase reveal an influence from the Mississippi River Valley? If these wares were initially found at Spiro, there might be some justification for this argument. However, this is not the case. Red-slipped wares are found in abundance in the Red River Valley in the twelfth and thirteenth centuries (Bruseth, Wilson, and Perttula 1995). These ceramics are associated with the Sanders site as well as numerous other villages and mound sites on both sides of the Red River. The red-slipped pottery of the Spiro phase is somehow linked to the development of these wares within sites related to the Sanders focus. Frankly (no pun intended), this phenomenon is not that big a deal. Red-slipped pottery is by no means a Mississippi Valley creation. A variety of wares with red slips can be found in the Southwest as well as along the Red River.

Another ceramic development of concern in Schambach's treatment of the Arkansas River Valley is the presence of textile impressions on vessel bases. This is stated as being absent from Caddoan ceramic assemblages in Arkansas and Louisiana. I have no problem with this. I question, however, whether this has a significant bearing on the origins or the continuity of Fourche Maline, Harlan, and Spiro phase occupations of the Arkansas River Valley. In searching the literature quite thoroughly for much of Oklahoma and over a span of some 45 years, the instances of ceramics with textile impressed bases appears to reside almost entirely within what has been labeled as Williams Plain or with synonymous styles (Bell and Baerreis 1951). These are found throughout eastern Oklahoma, along the Red River, and at sites of the Bryan focus farther upstream on the Red River.

There is also the issue of house form and mound construction. During the Spiro phase, houses of wattle and daub with two center posts are found. This pattern continues during the Fort Coffee phase. However, during the Fort Coffee phase, we also see the first appearance of circular structures. At this time, these remain poorly understood. Do these represent specialized building related to social/religious behavior or are these domestic dwellings? There are some parallels to this situation on the Plains. In the Washita River phase (A.D. 1250-1450; contemporaneous with the Spiro phase), we find rectangular wattle and daub houses also with two center posts (Brooks 1987). By the mid-16th century, we find 
Coronado encountering Plains Villagers (the Wichita) living in circular bee-hive grass houses. Of course, this architecture is also found among the Hasinai in Northeast Texas at a slightly later date (Bolton 1987). The point here is that this pattern seems well established across Oklahoma and Texas. It is my argument that architectural patterns are responses to degrees of sedentism, environmental conditions, and adaptations on the part of these Arkansas River and Red River Valley people (Brooks 1994). In a similar vein, flat-topped mounds occur in the Arkansas River and Red River valleys. On the north side of the Red River, these are found at the Clement site in McCurtain County and at the Nelson Mound in Choctaw County. In other words, I suspect the variation observed here is expressed in an eastwest difference which could be tied to environmental conditions as well as cultural themes.

\section{Trade}

The last area pertaining to the Arkansas River Valley and revisionist perspectives that I wish to address is that of trade and the entrepot model. Schambach (1993a) has suggested that the Nagle site in Oklahoma County and the Sanders site in Lamar County, Texas functioned as the equivalents of "Ports of Trade" or smaller gateways to the people on the Plains. The issue of Sanders and its importance as a trade center has been dealt with by Bruseth, Wilson, and Perttula (1995). Thus, I will limit my comments to the overall consideration of the entrepot model, the Nagle site, and trade with the Plains. Schambach would have us believe that Spiro had two substantial ports of trade on the periphery of the Spiroan area of influence. The initial question that should be examined is whether such a model is consistent with Spiroan society. Entrepots and "trading posts" are typically found in highly structured, extended rank-level or state-level societies. For example, Mayan society had "Ports of Trade" where commerce could function between states that were normally at war with one another (Berdan 1978; Polanyi 1963). We also find the Aztec making use of entrepots and "Ports of Trade". Complex chiefdoms such as we find in the southeast do not utilize such highly structured (political) and formal means of trade. As well documented in the literature, chiefdoms relied on the use of "trading partners" (Earle and Erickson 1976). These trading relationships were often extensive and complex, sometimes involving a number of down-the-line partners. However, they never relied on maintenance of a permanent settlement in the foreign territory. I would argue that Spiroan society probably maintained a trading partnership system with trading "power" vested in the hands of some of the priestly elites. We can also look at the ethnographic and ethnohistoric literature for further confirmation of the "trading partners" approach. Numerous French and Spanish accounts document the presence of individuals from another group within the settlement they were visiting (John 1975). Typically, these individuals were either present to arrange a trading agreement or to physically exchange goods. Often, these individuals would travel among a number of groups formalizing some type of down-the-line exchange. From these accounts, the traders would often visit these villages a couple of times a year. Of greater interest is the fact that these visitations were often with groups in conflict with the trader's people. There was obviously some type of arrangement whereby a trader traveled under a truce flag. On the Plains, there is a sophisticated macro-economy model documenting trade between southwestern Pueblos, middlemen, and agricultural Plains Villagers farther east (Spielman 1983). We find numerous accounts of the Caddo or Tejas participating in such trade relationships. The other type of exchange documented in the literature is the trade fair where different groups might rendezvous for exchanges. Based on La Harpe's famous description of the trade fair he visited somewhere in the vicinity of Tulsa, Oklahoms, numerous groups were present including some who were often in conflict with one another (Wedel 1971). All these facts point to the entrepot model being highly unlikely for Spiroan society.

Concerning the Nagle site, I have a number of 
comments. First and foremost, there is no evidence of a settlement at this location or in the immediate vicinity. This is based on Dr. Bell's efforts to find a village as well as later work by the Oklahoma Archeological Survey. It is also highly unlikely that a "Port of Trade" would include infants and young children. The $20+$ individuals recovered from the Nagle cemetery reflect a normalized population of an elderly male, young adult males and females, adolescents, children, and infants. In fact, $50 \%$ of the Nagle population is under 15 years of age, highly suspect for a group of traders. It is also unlikely that surrounding people, if on good terms with the traders, would permit them to reach the extent of malnutrition described by Brues (1953) and confirmed by Owsley. I think my idea of a refugee population is more parsimonious than that of trade. There is evidence of conflict and the population does not conform to what we normally find for Spiroan groups. As to why a group would be out on the Plains, I suspect there could be a number of reasons for this. First of all, it is well documented that relations between Caddoan groups were often strained. Caddos proper fought with one another, one confederacy against another as well conflicts within confederacies. They also had conflicts with groups such as the Wichita and the Kichai. I doubt that a Spiroan group would travel north or east because of the potential presence of Osage ancestral groups. They were also likely to encounter other Caddoan groups with whom they were not on friendly terms by traveling south or southeast. Thus, they might move west where groups of Wichita might be encountered. It is difficult to know whether the group they ultimately encountered was Wichita or another, nonCaddoan, people. Regardless, this meeting was apparently not a friendly meeting. Enough said about Nagle.

\section{CONCLUSIONS}

I find that there are substantial and important differences between what I view as Caddoan populations in the Arkansas River Valley and those found in southwestern Arkansas and northwestern Louisiana. And, I would ask, "Why shouldn't there be"? To assume that all groups of a general cultural pattern are alike falls into the trap that ethnicity sets for us. I would also say that I see nothing in these differences to suggest that Spiroan people are not Caddoan. Along this line, I will add that Susan Vehik has been examining the ethnohistoric record for any sort of information bearing on this problem (Vehik 1995). To date, there is confirmation for Wichita groups (the Tawakonis) in eastern Oklahoma in the 18 th century. However, there is no indication of the presence of Tunicas. More importantly, there is no indication among the Wichita of any contact with the Tunicas. This would be highly unlikely if the Tunicas were indeed the people responsible for Spiro. At present, we find no credibility to this argument.
What Schambach's revisionist perspectives has brought us to, however, is the realization that we don't really know the Arkansas River Valley all that well. There are numerous questions pertaining to subsistence, physical well being, and social/economic processes that need a lot of work. Despite $50+$ years of archaeology, many of the sites excavated by the WPA have not been examined. This is also true of the physical populations. We desperately need detailed ethnobotanical analysis at sites other than ceremonial centers. These same conditions also hold true for the Red River Valley (at least our portion of it). With the implementation of NAGPRA, I hope we can go forward in a cooperative spirit with the Caddo and Wichitas to examine these critical questions pertaining to their heritage.

Before closing, there are two issues which I think merit discussion. These are ethnicity and the dilemma posed between academic exercises 
and political reality.

1. The revisionist strategy for the Arkansas River Valley tradition has done a service for the academic community because it has brought us to the point where we must face the issue of ethnicity. In the past, archaeologists have causally approached ethnic diversity and cultural boundaries. I would argue that this can be ultimately be traced back to Clark Wissler and A. L. Kroeber and the cultural area concept where cultural and territorial boundaries neatly conformed. With passage of the Native American Graves, Protection, and Repatriation Act we are now faced with the consequence of establishing the relationships between prehistoric material culture and contemporary groups (correctly or erroneously). Archaeological studies of ethnicity have revealed the sometimes tenuous nature of these connections. In some cases, there appear to be clearly defined correspondence between material culture and identified ethnic groups. In other instances, we find substantive distinctions between groups speaking a common language such as that found between the Pawnee and Wichita proper. From the other perspective, we can cite examples of different and sometimes antagonistic groups that exhibit comparable if not identical material culture pattems (e.g., the Arikara and the Kansa). Where a cultural tradition is extremely widespread, it may be very difficult to define the ethnic boundaries that existed in prehistoric times. Here, the Plains Village tradition is a classic example, even considering our excellent ethnohistory and ethnography for the region. When proposing ethnic relationships between archaeological cultural patterns and known Native American groups, multiple paths of continuity need to be established. In Oklahoma, where we deal with the Caddo, the Wichita and the Pawnee, I wonder if some of the problem in these revisionist perspectives is not one of definition. Because of the multiple associations, we refer to Caddoan in a big C sense, meaning the various groups of Caddoan language affiliation (Caddo, Wichita, Kichai, Pawnee, etc.), whereas in southwestern Arkansas and northwestern Louisiana, Schambach need only be concerned with the small $c$ sense of the Caddo confederacies.

-2. The second issue of political reality is one to which all of us in the archaeological profession must become increasingly sensitive. In the past, archaeological argument could be expressed as a challenge to conventional views. Provocative perspectives during the early Binford years in fact became almost "de rigeur". This "shock" approach was initially intended to bring attention to a subject. We are now faced with the situation that such challenges have much broader legal and political implications. If we are to discuss issues of cultural affiliation (by the definition of NAGPRA) and deal with ethnicity, the cases we bring forth must be well grounded empirically. To do otherwise poses ethical and professional dilemmas to the archaeological community, museologists, and Native American people as well as compromising the ultimate disposition of the resources. 


\section{REFERENCES CITED}

Albert, Lois E.

1989 National Register Testing of Archeological Sites in the Lee Creek Watershed, Sequoyah County, Oklahoma. Report submitted to the Oklahoma Historical Society in fulfillment of subgrant 40-8830122.005. Ms. on file, Oklahoma Archeological Survey, University of Oklahoma, Norman.

Altschul, Jeffrey H. (editor)

1983 Bug Hill: Excavation of a Multicompo nent Midden Mound in the Jackfork Valley, Southeast Oklahoma. Report of Investigations 81-1. New World Research, Pollock, Louisiana.

Bell, Robert E.

1972 The Harlan Site, Ck-6, A Prehistoric Mound Center in Cherokee County, Eastern Oklahoma. Memoir 2. Oklahoma Anthropo-logical Society.

Bell, Robert E. and David A. Baerreis

1951 A Survey of Oklahoma Archaeology. Bulletin of the Texas Archaeological and Paleontological Society 22:7-100.

Bement, Leland C.

1994 Hunter-Gatherer Mortuary Practices During the Central Texas Archaic. University of Texas Press, Austin.

Berden, Frances F.

1978 Ports of Trade in Mesoamerica: A Reappraisal. In Mesoamerican Communication Routes and Cultural Contacts, edited by Thomas A. Lee, Jr. and Carlos Navarette, pp. 187-198. Papers of the New World Archaeological Foundation No. 40. Provo, Utah.

Bolton, Herbert E.

1987 The Hasinais: Southern Caddoans as Seen by the Earliest Europeans. Edited by Russell M.
Magnaghi. University of Oklahoma Press, Norman.

Boserup, Esther

1965 The Conditions of Agricultural Growth. Aldine Press, Chicago.

Brooks, Robert L.

1987 The Arthur site: Settlement and Subsistence Structure at a Washita River Phase Village. Studies in Oklahoma's Past 15. Oklahoma Archeological Survey, Norman.

1994 The Case for Sedentism Among Southern Plains Villagers. Paper presented at the 52nd Annual Plains Conference, Lubbock.

Brown, James

1978 Arkansas Valley Caddoan: The Spiro Phase. In Prehistory of Oklahoma, edited by Robert E. Bell, pp. 241-263. Academic Press, New York.

Brues, Alice M.

1957 Skeletal Material From the Nagle Site. Bulletin of the Oklahoma Anthropological Society 5:93-99.

ca.1977 The Spiro Skeletal Material. In The Burials, edited by James Brown. Unpaginated draft ms. prepared as Spiro Studies 5. University of Oklahoma, Norman.

Bruseth, James E., Diane E. Wilson, and Timothy K. Perttula

1995 The Sanders Site: A Spiroan Entrepot in Texas? Plains Anthropologist 40(153):223-236.

Burnett, Barbara

1989 The Bioarcheological Synthesis. In $\mathrm{Hu}$ man Adaptation in the Ozark and 
Ouachita Mountains, edited by George Sabo, III, Ann M. Early, Jerome C. Rose, Barbara A. Burnett, Louis Vogele, Jr., and James P. Harcourt, pp. 193-220. Research Series No. 31. Arkansas Archeological Survey, Fayetteville.

Duffield, Lathel F.

1969 The Vertebrate Faunal Remains from the School Land I and School Land II Sites, Delaware County, Oklahoma. Bulletin of the Oklahoma Anthropological Society 22: 1-10.

Earle, Timothy K., and Jonathan E. Ericson (editors)

1976 Exchange Systems in Prehistory. Academic Press, New York.

Fedick, Scott

1995 Indigenous Agriculture in the Americas. Journal of Anthropological Research 3(4):257-304.

Fritz, Gayle

1989 Evidence of Plant Use From Copple Mound at the Spiro Site. In Contributions to Spiro Archeology: Mound Excavations and Regional Perspectives, edited by J. Daniel Rogers, Don G. Wyckoff, and Dennis A. Peterson, pp. 65-87. Studies in Oklahoma's Past 16. Oklahoma Archeological Survey, Norman.

Galm, Jerry

1981 Prehistoric Cultural Adaptations in the Wister Valley, East-Central Oklahoma. Ph.D. dissertation, Washington State University. University Microfilms, Ann Arbor.

Galm, Jerry and Peggy Flynn

1978 The Cultural Sequence at the Scott (34LF-11) and Wann (34LF-27) and Prehistory of the Wister Valley. Archaeological Research and Management
Center, Research Series 3. University of Oklahoma, Norman.

Israel, Stephen

1979 Re-Examination of the Cookson Site. Studies in Oklahoma's Past 4. Oklahoma Archeological Survey, Norman.

John, Elizabeth

1975 Storms Brewed In Other Men's Worlds. Texas A \& M Press, College Station.

Kent, Susan

1986 The Influence of Sedentism and Aggregation on Porotic Hyperostosis and Anemia: A Case Study. Man 21:605636.

Lopinot, Neal H.

1991 Part I: Archaeobotanical Remains. In The Archaeology of the Cahokia Mounds ICT-II: Biological Remains, edited by Neal H. Lopinot, Lucretia S. Kelley, George S. Milner, and Richard Paine, pp. 160-162,168-169. Illinois Cultural Resources Study 13. Springfield.

Ortner, Donald J.

1991 Theoretical and Methodological Issues in Paleopathology. In Human Paleopathology, edited by Donald J. Ortner and Arthur Auferheide, pp. 511. Smithsonian Institution Press, New York.

Ortner, Donald J. and Walter G. J. Putshar

1985 Infectious Diseases; Identification of Pathological Conditions in Human Skeletal Remains. Smithsonian Contributions in Anthropology 28:104-138.

Pauketat, Timothy

1994 The Ascent of Chiefs: Cahokia and Mississippian Politics in Native North America. University of Alsbama Press, Tuscaloosa. 
Polyani, Karl

1963 Ports of Trade in Early Societies. The Journal of Economic History 23:30-45.

Rohrbaugh, Charles L.

1982 Spiro and Fort Coffee Phases: Changing Cultural Complexes of the Caddoan Area. Ph.D. dissertation, University of Wisconsin. University Microfilms, Ann Arbor.

Schambach, Frank F.

1990a The Place of Spiro in Southeastern Prehistory: Is It Caddoan or Mississippian? Southeastern Archaeology 9(1):67-69.

1990b The Northern "Caddoan Area" Was Not Caddoan. Caddoan Archaeology Newsletter 1(4):1-6.

1993a Some New Interpretations of Spiroan Culture History. In Archaeology of Eastern North America: Papers in Honor of Stephen Williams, edited by James B. Stoltman, pp. 187-230. Archaeological Report 25. Mississippi Department of Archives and History, Jackson.

1993b Spiroan Entrepots at and Beyond the Western Border of the Trans-Mississippi South. Caddoan Archaeology Newsletter 4(2):11-26.
Smith, Bruce

1989 Origins of Agriculture in Eastern North America. Science 246:1566-1571.

Spielmann, Katherine A.

1983 Late Prehistoric Exchange Between the Southwest and Southern Plains. Plains Anthropologist 28:257-272.

Tainter, Joseph

1980 Behavior and Status in a Middle Woodland Mortuary Population from the Illinois Valley. American Antiquity 45:308-313.

Vehik, Susan C.

1995 Caddoan Occupation of Northeastern Oklahoma. Paper presented at the 17 th Annual Flint Hills Conference, Norman.

Wedel, Mildred M.

1971 J.-B. Bénard, Sieur De La Harpe: Visitor to the Wichitas in 1719. Great Plains Journal 10:37-70.

Wyckoff, Don G.

1980 Caddoan Adaptive Strategies in the Arkansas Basin of Eastern Oklahoma. Ph. D. dissertation, Washington State University. University Microfilms, Ann Arbor. 